\title{
Athletic expatriation and volleyball: adaptation to the new club
}

\author{
Ivan Wallan Tertuliano', Afonso Antonio Machado², Vivian de Oliveira³, José Maria Montiel³, Daniel Bartholomeu, \\ Silvia Deutch².
}

\begin{abstract}
Background: The expatriation of athletes occurs, most of the time, without proper preparation, which may compromise the athlete's adaptation to the new work club. In this way, understanding the factors that can help in this process becomes necessary, because one can plan interventions to improve the athlete's adaptation. Objective: To analyze the adaptation of the Volleyball athletes after changing to a new club and city to continue their career in the national and the international context. Methods: The sample was composed of 68 people ( 48 athletes and 20 ex-athletes), being 43 males and 25 females with mean age of 27 years. Participants were divided into 2 groups: G1 (International Athletes) and G2 (National Athletes). It was used a questionnaire with structured questions called "Questionnaire: the process of expatriation of volleyball players" and only the questions that were related to the objective of the study were used. The analysis of the results was conducted through analysis between groups and intragroup. Results: Both groups showed good adaptation to the new club, very influenced by the relationship with the athletes, coach and technical committee. Conclusions: The participants demonstrated adequate coping strategies and personal resources. In addition, it can be speculated that for an adequate adaptation to the new club, athletes must present adequate resources to face this new reality, demonstrating the need to prepare the athletes before the expatriation process.
\end{abstract}

Keywords: Psychology of Sport; Expatriation; Volleyball; Adaptation.

\section{INTRODUCTION}

The expatriation (migration) of athletes has existed since the early decades of the 20th century but accelerated after 1996, due to the change in the European legislation after the Bosman case. After 1996, the mobility of Soccer players, in the international context, grew and the percentage of foreigners in European Football leagues also grew. In this context, Brazil leads the ranking of countries with the highest number of players in the European leagues, followed by Argentina and Serbia ${ }^{(1)}$. Another factor that contributed to the increase of expatriate players was the Pelé law (Law 9.615/98), as it instituted the free pass ${ }^{(2)}$. Before the Pele law, the pass was the link between the player and the club and after the law the pass was replaced by a labor and sports bond, giving the player the right to sign a contract ${ }^{(3)}$. No different from football, volleyball athletes undergo the same characteristics, bond and marketing ${ }^{(2)}$. In Volleyball there are many examples of these processes starting in 1960, when Brazil began to gain recognition in the world scenario due to the victories of the Brazilian Volleyball team ${ }^{(4)}$. In view of that, in 1978 the Brazilian players William Silva, Bernard Rajzman, Montanaro and Bacalhoca were hired to play in the Italian championship.
This fact has a strong influence of the market relations that the Volleyball has with the sponsoring companies, which generated a Spectacularization of Volleyball, mainly from the decade of 1990 . Thus, with the greater visibility of Brazilian Volleyball, there is also a greater demand for Brazilian athletes to work outside Brazil.

As a social phenomenon, the expatriation of athletes between countries or even regions of the country is also called migration $^{(1,2)}$ or athletic migration ${ }^{(5)}$. This process is the sending of people by an organization to live and work in another country for a period of time greater than 1 year. In sports, in other words, the expatriation of athletes can be understood as the exchange of country by an athlete to continue to compete in the sport in which he or she works, or even in another sport ${ }^{(6)}$. In the sphere of sport, this process was investigated for the most part in Football(5,7-11), which opens justification for this study, since to date few studies have been conducted with other sports ${ }^{(12,13)}$ and only 3 studies with Volleyball(2,5,14).

In addition, the studies have pointed to a model of sports expatriation that does not present preparation or previous training for the athlete ${ }^{(14,15)}$, demonstrating that there are

Corresponding Author: Ivan Wallan Tertuliano - Address: Estrada de Itapecerica, 5859, Capão Redondo, CEP 05858-001. Tel.: +55 11 2128-6000. São Paulo/SP, Brasil. E-mail: ivanwallan@gmail.com

(1) Centro Universitário Adventista de São Paulo (UNASP), São Paulo (SP), Brasil.

Full list of author information is available at the end of the article.

Financial support: The authors declare that there was no financial support.

Submission date 30 August 2018; Acceptance date 26 October 2018; Publication date xx Mês xxxx 
gaps in the expatriation process of athletes and the need for adequate strategies for expatriation planning with the aim of minimizing possible psychological discomforts ${ }^{(6)}$, and contributing to an appropriate adaptation ${ }^{(2,5)}$. Therefore, investigating the process of sports expatriation can contribute to the preparation of athletes as well as their insertion in the new team, minimizing the psychological and social damages that this process may bring. Since Volleyball is the second most practiced sport in Brazil(16), the understanding of the expatriation process among volleyball players is very important. Thus, the objective of this study is to analyze the adaptation of the Volleyball athletes after changing to a new club and city to continue their career in the national and the international context.

\section{METHODS}

The present study is a quantitative-qualitative approach, since qualitative analyzes and their confirmation by inference are considered important.

\section{Participants}

Volleyball athletes and ex-athletes voluntarily participated in the study. According to the literature, ex-athletes are able to comment on how they have faced adversities throughout their careers and the results of these experiences over time ${ }^{(14,17)}$, giving support for the inclusion of ex-athletes in this study. As a form of identification of the ex-athlete, the following question was used: "Did you stop playing in championships?". This question served as a criterion for separating the participants in: athlete and ex-athlete. Regarding the criteria for research participation, one of it was to be professionalized, being observed by the following question: “Did you become professional?". In case of negative, the participant would be discarded from the sample. Another criterion for participation was the performance in clubs from different cities of the hometown, being observed with the question about having defended teams from other countries and having defended other clubs. Finally, the volunteer should be over 18 years old. Thus, 4 participants did not meet the inclusion criteria. After the criteria mentioned above, 68 volunteers ( 43 men and 25 women) participated in the study. Of these, 48 are athletes ( 35 men and 13 women), and 20 are ex-athletes ( 8 men and 12 women), with a mean age of 27.29 years $(S D=8.73)$. Participants were divided into 2 research groups: $\mathrm{G} 1$ (International Athletes - active in other countries) with 30 participants; G2 (National Athletes - active in Brazil, but in a different city from hometown) ${ }^{(18)}$, with 38 participants.

In order to direct the participant to one of the sample groups, the following question was used: "Have you ever played in a club from another country?". Depending on the answer, they were directed to the questions that referred to international or national expatriation. All participants completed the Informed Consent Form (ICF) prior to their participation in the research.

\section{Instrument}

In this study, the instrument used was elaborated by Tertuliano(2), and used by Tertuliano et al. ${ }^{(14)}$. The instrument was prepared in a questionnaire form called: "Questionnaire: The process of Expatriation of Volleyball Players". For the elaboration process, were consulted three judges (two psychologists and one physical educator) with more than 10 years of experience and with expertise in the area. The questionnaire was elaborated dividing the questions into 2 parts: the first part presents a question that seeks information about the socioeconomic characteristics and dynamics of participants' expatriation; the second part presents questions that seek to understand the adaptation of the participant to the expatriation process. In this way, the questions of the first part served to identify the participant, to present the sample and to compare the participants who answered the questionnaire with the participants who gave the ICF. Facing this comparison, participants who did not submit the EHIC but answered the questionnaire would be discarded from the study. The questions used for such objectives of sample characterization and control of the delivery of the ICF are shown in Chart 1.

The second part of the instrument presents only closed and mandatory questions and has been developed with several response categories, such as Likert scale, serving two functions: (1) emphasize relevant aspects of the variables and (2) enable the participant to choose an intermediate category of response. It should be noted that this part of the instrument seeks to understand the adaptation of the expatriate to the process of changing city and/or country. So the possibilities of answers are: 1 (totally disagree), 2 (disagree), 3 (agree a little), 4 (agree) and 5 (totally agree) or 1 (very bad), 2 (bad), 3 (undecided), 4 (good) and 5 (very good) for adaptation questions. At this stage, the instrument presents questions for the participants of the 2 groups: $\mathrm{G} 1$ and $\mathrm{G} 2$. The questions seek to understand the adaptation of the expatriate to the new context and what are the factors facilitated in the adaptation process, providing a qualitative and quantitative analysis. It should be noted that in the present questionnaire some questions presented common sense for the 2 groups regarding the objective of the questions, even though they were answered in questionnaires unique to each group. It was used in this study only those questions that had in their structure aspects correspondent to the purpose of the manuscript, i.e., the process of adaptation of the athlete to the new club. Thus, questions related to other objectives were discarded from the analyzes. Therefore, the second phase questions were those that, in addition to responding to the objective of the study, were adjusted to the Rasch model after the analysis of TRI (Theory of Response to the Item), performed by Tertuliano(2). The objective of this analysis was to evaluate 
Chart 1: Questions used in the first stage, developed by Tertuliano ${ }^{(2)}$, for both groups (G1 and G2).

\begin{tabular}{|c|c|}
\hline \multicolumn{2}{|r|}{ Questões utilizadas da primeira etapa do instrumento } \\
\hline 1. & Name of participant: \\
\hline 2. & Date of birth: \\
\hline 3. & Age: \\
\hline 4. & City of birth: \\
\hline 5. & State of birth: \\
\hline 6. & Country of birth: \\
\hline 7. & Sex: ( )Male ( )Female \\
\hline 10. & Sport that practiced or practiced: \\
\hline 11. & Currently training this sport? ( )Yes ( )No \\
\hline 26. & Already professionalized? ( )Yes ( )No \\
\hline \multirow[t]{2}{*}{31.} & $\begin{array}{l}\text { Have you stopped playing championships? ( )Yes ( )No (go to } \\
\text { question 34) }\end{array}$ \\
\hline & If the answer is yes \\
\hline 32. & Since when did you stop playing championships? \\
\hline 47. & $\begin{array}{l}\text { Have you ever defended clubs from another country? ( )Yes ( )No (go } \\
\text { to question 101) }\end{array}$ \\
\hline \multicolumn{2}{|r|}{ Exclusive questions from the $\mathrm{G} 1$ group } \\
\hline 48. & $\begin{array}{l}\text { Were you playing at any club in Brazil when you left Brazil for the first } \\
\text { time? } \\
\text { ( )Yes ( )No }\end{array}$ \\
\hline 49. & What was the first club you defended in another country? __ (optional) \\
\hline 50. & Which country is the first club to defend outside of Brazil? \\
\hline 51. & Brazilian club defending before leaving Brazil: _____ (optional) \\
\hline \multicolumn{2}{|r|}{ Exclusive questions from the $\mathbf{G} 2$ group } \\
\hline 101. & Have you defended yet another club? ( )Yes ( )No (Submit form) \\
\hline 102. & $\begin{array}{l}\text { Have you ever defended a club from another city? ( )Yes (go to } \\
\text { perception issues - National) } \\
\text { ( )No (Submit form) }\end{array}$ \\
\hline $\begin{array}{l}\text { Note. } \\
\text { quest }\end{array}$ & $\begin{array}{l}\text { The variable number refers to its number in the Tertuliano } \\
\text { ionnaire(2). }\end{array}$ \\
\hline
\end{tabular}

the unidimensionality of the instrument, i.e., the analysis of principal components of residues by the Rasch model. Thus, it was verified the items that fit the model, then evaluated the difficulty and ability of items and people, respectively, and with that, used only the questions adjusted to the model for the inferential analysis phase. After all the analysis of items to the Rasch model, it was compared the infit and outfit values of contrast analysis (acceptable values between 0.50 and 1.50 and correlation less than 0.30 ), item map and value of Theta, and the adjusted questions are found in Chart 2.

\section{Methodological procedures}

The research respected the legal principles and all the ethical standards of research with human beings of the National Health Council (CNS), Resolution 466/12. Thus, the research was first presented to the Ethics and Research
Chart 2: Questions used after analysis of items adjustment to Rasch model, developed by

\begin{tabular}{|c|l|}
\hline \multicolumn{2}{|c|}{ Similar questions for the $\mathbf{2}$ groups } \\
\hline 24. & The relationship with the new coach assisted in the adaptation. \\
\hline 25. & $\begin{array}{l}\text { The relationship with the players of the new team assisted in the } \\
\text { adaptation. }\end{array}$ \\
\hline 26. & $\begin{array}{l}\text { The relationship with the technical committee of the new club } \\
\text { assisted in the adaptation. }\end{array}$ \\
\hline 27. & $\begin{array}{l}\text { The relationship with the leaders of the new club assisted in the } \\
\text { adaptation. }\end{array}$ \\
\hline 30. & $\begin{array}{l}\text { The conditions of the training structure in the new club assisted in } \\
\text { the adaptation. }\end{array}$ \\
\hline 31. & $\begin{array}{l}\text { The training conditions (times and routine) in the new club assisted } \\
\text { in the adaptation. }\end{array}$ \\
\hline 37. & The new club has respected my time of adaptation. \\
\hline 38. & The new club has given me new friends. \\
\hline 41. & In the new club I train with more will and determination. \\
\hline 42. & I focus more on training in my new club. \\
\hline 43. & I am more popular in my new club. \\
\hline 44. & I help more my team mates in my new club. \\
\hline 45. & I respect more the coach's authority in my new club. \\
\hline
\end{tabular}

Note. The variable number refers to its number in the Tertuliano questionnaire(2).

Tertuliano( $^{(2)}$.

Committee (CEP) of the Institute of Biosciences of Rio Claro/Universidade Estadual Paulista, with number 1.537.814. After the approval the athletes and ex-athletes of Volleyball were invited through the Internet (Facebook and E-mail) to participate in the study. At this stage the participants received information about the purpose of the study, and were advised that they could give up in any of the stages. As a way to better organize the participants of the present study, a closed group (called "VOLEIBOL FORA DO BRASIL" - Volleyball outside Brazil) was created on Facebook. After this, respecting all the ethical standards of research with human beings (CNS Resolution 466/12), contacts were made with the participants who accepted to participate in the research and sent an E-mail with the ICF. Participants should read, complete and sign the TCLE and return it through e-mail, Post Office or personally. The next stage was characterized by the application of the instrument, which, according to the CEP, could be conducted in printed or electronic form (internet), and the participants who did not completed and signed the ICF were discarded from the study. All the participants chose to answer the questionnaire electronically, so the questionnaire was transcribed to Google Forms. On average, participants took 40 minutes to respond to the questionnaire. In order to control participation, all questionnaires and ICF were verified, in order to ensure that only participants who delivered ICF could participate in the sampling, and to evaluate the group that the participants would be directed to. 


\section{Analysis procedures}

This study presents descriptive and inferential analyzes, since the quantitative-qualitative approach was assumed as a way of understanding the data and, with this, to be able to respond to the objectives of the study. Regarding the analyzes, they were only conducted on the questions mentioned in the table 2. The questions of the first stage served to present the participants and separation in the sample group, and the descriptive and inferential analyzes were only conducted in the questions of the second stage, which were constructed in Likert scale. For this, analyzes were carried out between groups and intragroup. According to the central limit theorem, the larger the sample size, the distribution of the means will be closer to a normal distribution. The literature suggests that in a group with more than 30 participants it is possible to assume normality and homogeneity of variance without the use of tests ${ }^{(19)}$. Therefore, normality was assumed using the Alpha value of 0.05 for significant differences. Regarding the scoring scales of the second stage, it is important to note that the increase of points indicates a higher incidence of the expected factor in that response. For descriptive analysis, it was used median and mode, since it offers better information for qualitative analysis. For the inferential analyzes between groups was used the t-test for independent samples, and for intra-group analysis were used the one-way ANOVA and Pearson's correlation. When found significant intragroup differences were conducted the post hoc tests. To control the type 1 error was used the Holm's sequential Bonferroni procedure ${ }^{(19)}$. All analyzes were performed with the SPSS Statistics, version 20.

\section{RESULTS}

As previously mentioned, the results were evaluated on the athlete's adaptability to the new club, using only the questions of the second part of the instrument that had been adjusted to the Rasch model. For better understanding, the results were divided into 2 stages: the first in relation to the athlete's adaptation to the new club (using the items 24, 25, $26,27,30,31$ and 37 ) and the second stage in relation to socialization of the athlete in the new club (using the items $38,41,42,43,44$ and 45 ). On the adaptation of the athlete to the new club, in a qualitative analysis, it was observed that the two groups showed a good relation with the coach, as well as a great relation with the teammates. In addition, participants of the $G 2$ pointed out the structure of the training filed and the training conditions as favorable for adaptation, and perceived that the club was more tolerant about the adaptation time. Such information was partially confirmed by the inferential analyzes (Table 1). In relation to the athlete's ability to adapt to the new club, the $t$ test for independent samples showed a significant difference between groups only for the training conditions (time and routine) in the new team to help with adaptation ( $p=0.037$ ) (question 31 ). This value demonstrated that the athletes of group $\mathrm{G} 2$ perceived more the training conditions in the process of adaptation as a beneficial factor.

In the intragroup comparison, conducted by the Anova one-way test, the results showed significant differences for Group G1 [F (6.174) = 3.943; $p<0.002)$. Concerning the location of the difference, Bonferroni's Post hoc test presented only significant difference between item 24 and

Table 1: Analysis of groups on adaptation to the new club $(n=68)$.

\begin{tabular}{|c|c|c|c|c|c|}
\hline Variable & Group & $\mathbf{N}$ & Median & Mode & $\begin{array}{c}\text { T test for } \\
\text { independent } \\
\text { samples }\end{array}$ \\
\hline \multirow{2}{*}{ 24. The relationship with the new coach assisted in the adaptation. } & G1 & 30 & 4.00 & 4 & \multirow{2}{*}{0.453} \\
\hline & $\mathrm{G} 2$ & 38 & 4.00 & 5 & \\
\hline \multirow{2}{*}{ 25. The relationship with the players of the new team assisted in the adaptation. } & G1 & 30 & 4.00 & 4 & \multirow{2}{*}{0.474} \\
\hline & G2 & 38 & 4.00 & 5 & \\
\hline \multirow{2}{*}{ 26. The relationship with the technical committee of the new club assisted in the adaptation. } & G1 & 30 & 4.00 & 4 & \multirow{2}{*}{0.692} \\
\hline & G2 & 38 & 4.00 & 4 & \\
\hline \multirow{2}{*}{ 27. The relationship with the leaders of the new club assisted in the adaptation. } & G1 & 30 & 4.00 & 4 & \multirow{2}{*}{0.927} \\
\hline & $\mathrm{G} 2$ & 38 & 4.00 & 4 & \\
\hline \multirow{2}{*}{ 30. The conditions of the training structure in the new club assisted in the adaptation. } & G1 & 30 & 4.00 & 3 & \multirow{2}{*}{0.766} \\
\hline & G2 & 38 & 4.00 & 4 & \\
\hline \multirow{2}{*}{ 31. The training conditions (times and routine) in the new club assisted in the adaptation. } & G1 & 30 & 3.50 & 3 & \multirow{2}{*}{$0.037^{*}$} \\
\hline & $\mathrm{G} 2$ & 38 & 4.50 & 5 & \\
\hline \multirow{2}{*}{ 37. The new club has respected my time of adaptation. } & G1 & 30 & 4.00 & 4 & \multirow{2}{*}{0.190} \\
\hline & $\mathrm{G} 2$ & 38 & 4.00 & 5 & \\
\hline
\end{tabular}

Note. The variable number refers to its number in the Tertullian questionnaire (2016). *significant difference between groups. 
Table 2: Analysis between groups about socializing in the new club $(n=68)$.

\begin{tabular}{|c|c|c|c|c|c|}
\hline Variable & Group & $\mathbf{N}$ & Median & Mode & $\begin{array}{l}\text { T test for } \\
\text { independent } \\
\text { samples }\end{array}$ \\
\hline \multirow{2}{*}{ 38. The new club has given me new friends. } & G1 & 30 & 4.00 & 5 & \multirow{2}{*}{0.588} \\
\hline & $\mathrm{G} 2$ & 38 & 5.00 & 5 & \\
\hline \multirow{2}{*}{$\begin{array}{l}\text { 41. In the new club I train with more will and } \\
\text { determination. }\end{array}$} & G1 & 30 & 4.00 & 4 & \multirow{2}{*}{0.841} \\
\hline & $\mathrm{G} 2$ & 38 & 4.00 & 5 & \\
\hline \multirow{2}{*}{ 42. I focus more on training in my new club. } & G1 & 30 & 4.00 & 4 & \multirow{2}{*}{0.737} \\
\hline & $\mathrm{G} 2$ & 38 & 4.00 & 5 & \\
\hline \multirow{2}{*}{ 43. I am more popular in my new club. } & G1 & 30 & 4.00 & 4 & \multirow{2}{*}{0.171} \\
\hline & G2 & 38 & 3.00 & 3 & \\
\hline \multirow{2}{*}{ 44. I help more my team mates in my new club. } & G1 & 30 & 4.00 & 5 & \multirow{2}{*}{0.625} \\
\hline & G2 & 38 & 3.00 & 5 & \\
\hline \multirow{2}{*}{ 45. I respect more the coach's authority in my new club. } & G1 & 30 & 4.00 & 4 & \multirow{2}{*}{0.613} \\
\hline & $\mathrm{G} 2$ & 38 & 3.50 & 5 & \\
\hline
\end{tabular}

Note. The variable number refers to its number in the Tertullian questionnaire (2016).

items 25,26 and $31(p<0.025)$. This information points to the relationship with new players and coaching staff are more relevant for athletes' adaptation than relationships with coach. Using Pearson's correlation to verify the correlation between variables, it is observed that the $\mathrm{G} 1$ showed a strong correlation between item 24 and items $25(r=0.715, p=0.000)$ and $26(r=0.802, p=0.000)$. These correlation values demonstrate that the team players and the coaching staff are important for the athlete's adaptation, pointing out the importance of teamwork with the adaptation of the expatriate. Regarding the intragroup analysis for $\mathrm{G} 2$, the results showed significant differences $[F(3.282,121.437)=1.637 ; p<0.019]$. Regarding the location of the difference, it is between item 31 and items 26,27 and $30(p<0.048)$. This information indicates that the training conditions were important for the adaptation to the new club. The correlation results showed a strong correlation between all items $(r>0.70, p=0.000)$. These values indicate that the adaptation to the new club for $\mathrm{G} 2$ athletes has a strong influence on the whole context, pointing out again the importance of the teamwork to better adapt the athlete to the new club. The next stage of analysis of the items evaluated the athlete's socialization in the new club. In the qualitative analysis, it was observed that the new club provided new friends for the two groups and this may have led athletes to train more willingly, concentrate more on training, help their teammates to be more popular in the team and respect the coach authority. In addition, the qualitative analysis showed that $\mathrm{G} 1$ participants presented more these characteristics than the G2. This information was partially confirmed by inferential analysis (Table 2).

Facing the inferential analysis, the $t$ test for independent samples did not present a significant difference between groups ( $p>0.05$ ). This data suggests that the participants of the two groups had very similar socialization in the new club. In the intragroup comparison, the results showed significant differences for $\mathrm{G} 1[\mathrm{~F}(2.663,77.217)=4.227 ; \mathrm{p}<0.010]$. Concerning the difference, post hoc presented a significant difference between item 38 and the other items $(p<0.05)$. This information demonstrates that the participants used the new club to form new friendships, a good indication of adequate social interaction. For correlation between variables, it is observed that $\mathrm{G} 1$ presented a strong correlation between item 45 and items 41,42 and $44(r>0.70, p=0.000)$ and between 41 and $42(r=0.958, p=0.000)$, demonstrating a correlation between training more willingly and focusing more on training, and showing that respect for the new coach is an interaction factor for greater dedication to training and to help more teammates, which may have contributed to the formation of new friendships in the club. Concerning intra-group analysis for $\mathrm{G} 2$, the results showed significant differences $[F(3.277,121.255)=5.160 ; p<0.0003]$. The post hoc presented a significant difference between item 38 and the other items $(p<0.05)$. This corroborates with the information from the $G 1$, demonstrating that the participants used the new club to form new friendships, a good indication of proper social interaction. The correlation values presented a strong correlation between items 41,42 and $44(r>0.70$ e $p=0.000)$, demonstrating a strong interaction between the athlete's involvement, concentration and cooperation in training in the new club.

\section{DISCUSSION}

According to the objective of this research, which was to analyze the adaptation of the Volleyball athletes to the new club, after changing their team and city to continue their career, 
both in the international and national context, the results found were discussed below. However, it should be pointed out that in the present study the selected participants are part of the proposed theoretical work for thematic regardless of whether it is an international or domestic expatriation. Corroborating with the aforementioned theoretical point of view, some studies ${ }^{(6,18)}$ argue that the expatriation process may involve a change of country, state or city, reinforcing the use of expatriate athletes inside and outside of the hometown. Regarding generalization of the data, the sample size becomes relevant because it will determine if the results are possible generalization.

So that the sample is representative and, therefore, generalizes the results, Vochkell(20) suggests a number of formulas for the calculation of a representative sample, including the level of probability and the amount of sample error that may be acceptable. However, it should be noted that the present study discusses the power of representativeness within the Volleyball and not the representativeness within the sporting environment, that is, the size of the sample becomes representative only for the context of Volleyball. However, when considering a survey, the time and cost of the sample should also be taken into account for the sample size. The cost of travel for questionnaire application (some participants live in countries in Europe, Asia, North America and the Middle East) and the time that the participant had available to answer the questionnaire (some athletes were in the competitive period) were taken into account, which limited the sample only to Volleyball athletes and, consequently, the generalization of results beyond Volleyball became infeasible. Thus, returning to the discussion of the results found in the present study, the findings showed that there was a good adaptation to the new club, independently of the sample group and that this adaptation is correlated with the socialization with the team members (technical committee, athletes and coach). According to Machado ${ }^{(15)}$, clubs do not care about the player's adaptation process, differing from the results of this study, since the groups presented the adaptation factor and respect to the time to adaptation as relevant factors for adaptation of the athlete to the new club, as seen in other studies ${ }^{(5)}$. In addition, the results indicate that the clubs contributed to the athlete's adaptation. This fact demonstrates a relationship between clubs and athletes different from the relationship that Soccer clubs have with athletes ${ }^{(7,15)}$. This relationship can be understood in a way that the Volleyball clubs respect more the adaptation of the athlete. Thus, the results of this study corroborate with the results of the literature ${ }^{(5,7,8,21,22)}$, demonstrating that there was a good relationship between the expatriate and the team (team players and coaching staff), possibly due to the athletes' awareness of cultural diversity, which allowed respect for differences, favoring the establishment of working relationships between team members. Therefore, in the present study, as well as in some literature studies ${ }^{(5,7,8,11,15)}$, the relationship with the other team members positively influenced the adaptation. Concerning the athlete's relationship with the new club, both groups showed greater concentration and dedication of the athletes to the training, demonstrating motivation.

In the sports field, motivation is an important variable for coaches and athletes, who agree that motivation is one of the fundamental elements for athletic performance ${ }^{(23)}$. Motivation can be understood by a hypothetical construct of internal and external forces that lead to a motive to one to strive, act, persist or work towards a goal|(24). Sports performance has a great relation with motivation and one of the proposals that contributes to the explanation of the factors related to income is the cognitive, motivational and relational transactional model ${ }^{(25)}$. In this theoretical model, people react to situations of adaptation using psychological processes that contain cognitive, motivational and relational factors. Given the results of this study, the reasons are related to the relationships created within the club with the team members independently of the sample group, corroborating the hypothetical construct about motivation. The present study suggests that the club's friendships and the technical committee have respected the athlete's time of adaptation were relevant reasons for the athlete, causing them to try harder in the training, demonstrating more dedication and contributing to their adaptation to the new club. This adaptation is related to three specific psychological needs: needs of autonomy, competence and establishment of bonds ${ }^{(26)}$, which are innate, integrated and interdependent, i.e., they reinforce and strengthen the other. This good relationship between teammates may also have influenced the behavior of the expatriate (international and national) in the new team, since the good environment contributes to the generation of new friendships ${ }^{(2)}$. Continuing, the athletes were placed in front of external demands and had to use of their psychological capacities to deal with them, i.e., they used of mental processes to solve psychological confrontations ${ }^{(25)}$. When considering psychological processes, in adapting to the new club, consideration should be given to analyzing the transaction between the participant and the context (club). Assuming that the new context can generate stress, in the present study stress was shown as a positive situation, since the participants of the two groups managed to efficiently deal with adaptation to the club. This aspect refers to the Multidimensional Anxiety Theory ${ }^{(27)}$, in which stress and anxiety can be interpreted by athletes as facilitators of performance as occurred in the present study. More than the psychological confrontation, the participants' adaptation to the results presents the interaction between the participants and the context, since the results showed a relation between the athlete's adaptation to the new club and the friendships constituted within the club, mainly with other athletes and members of the technical team. Thus, the interaction between the participants and the context was more than a 
simple interaction, it meant the construction of a relational meaning ${ }^{(25)}$. This relationship led the athlete to build new friendships and, thus, to have a good relationship with the club, which contributed to their adaptation (in the club) to the expatriation process. In other words, the friendships built and the athlete's perception that the expatriation is a positive thing led him to self-confidence, which served as a strategy for stress management ${ }^{(27)}$. All this set of skills of the athletes used to adapt to the adverse circumstance of the expatriation is known by strategies of confrontation or coping ${ }^{(23)}$.

Coping is a set of strategies people use to adapt to adverse circumstances and deal efficiently with these often stressful situations ${ }^{(23)}$. Therefore, the results of the study on the adaptation of athletes to the new club for both groups suggest that athletes used coping strategies to adapt to adverse circumstances. More than that, the results suggest that the coping strategy, possibly used by the athletes, was the active coping with a focus on effort and work, and the confrontation with adversity ${ }^{(23,28)}$. Another factor that may have contributed to the good adaptation of the athletes to the new club is the fact that they have become professionalized. The studies show that professional athletes are more confident and motivated to overcome any barriers during sports practice ${ }^{(28)}$. In addition, elite professional athletes have better psychological skills to deal with adverse events than expected ${ }^{(29)}$. As in this study the sample was composed of elite professional athletes, this hypothesis can explain the results. Maybe, as suggest by Oliveira ${ }^{(28)}$, professional athletes have better defined coping strategies than amateur athletes, so they are able to face stressful situations in a way that does not disrupt their performance, in addition to formulating their goals better, which makes them more confident in facing adversities ${ }^{(29)}$. These strategies may have contributed to the adaptation to the new club (in the two sample groups). Added to that, Oliveira(28) suggest that older athletes deal better with stressful situations. As in this study the international and national sample was composed of professional athletes and with a mean age above 24 years (International $=30$ years and National $=24$ years), it is possible to explore this information. Therefore, the athletes due to their age had a good adaptation to the new club, because they presented coping strategies adequate to face the adverse circumstance ${ }^{(2)}$.

Finally, the results showed a strong influence of the coach in the good socialization and, consequently, in the good adaptation of the athlete to the adversities of the expatriation (for both groups). These results are related to the results of Keegan et al. ${ }^{(30)}$, which demonstrated the behavior of the coach as a positive influencer for motivation of the athletes. Thus, it can be inferred that the athletes had adequate adaptation to the new club through the good behavior of the coach, as influencer and responsible for ensuring safety for the athlete, which strengthened their coping strategies towards expatriation $^{(14,28,30)}$.

\section{CONCLUSIONS}

Responding to the objective of the present study, it can be considered that the athletes of the two groups presented similar adaptive behaviors to the new club, such as, for example, the greater involvement in the training routines. This information was supported by the results that showed good social interaction within the club for the athletes of the two groups and, in addition, formed new friendships with the members of the team, had a good relationship with the technical commission, generating a greater dedication to the training and cooperation with teammates and technical staff. The athletes demonstrated a good adaptation to the new club, showing development of the personal resources related to the demand of the context. Therefore, the adaptation of the Volleyball athlete was adequate in the present study, since the athlete presented a favorable adaptation to the different adversities that the context imposed, such as new training routines and teammates. Thus, the results of the present study are in line with the results of the literature ${ }^{(5,7,8,11,14)}$, with respect to the adaptation of the athlete in a new context, in this case, influencing the performance of the athlete. Some personal mechanisms were fundamental for maintaining, improving and correcting motivational skills and resources after expatriation and the uncertainty of the new environment, such as coping. As preparation of athletes, one should think of intervention models that prepare them for expatriation because in the present study the participants were all elite athletes and, according to the literature, amateur athletes have fewer psychological resources to deal with the uncertainties ${ }^{(28)}$. Thus, when thinking about training programs for athletes to acquire adequate psychological skills to deal with the new club, intercultural adjustment issues must be taken ${ }^{(2,5,6)}$, as well as the preparation of the club that will receive the new athlete, who must be aware of the period of adaptation of the athlete and that during that period the performance of the athlete can oscillate. The limitation of the present study is not to have sought information about the athlete's adaptation to the team members (coaches, managers and coaching staff), demonstrating the need for studies that, in addition to using information obtained from athletes, process of adaptation of the expatriate from the perspective of other people involved, such as the technical committee of the new club. It should be noted that the results of this study are limited to generalization only for the context of Volleyball, which demonstrates the need for investigations of the adaptation of athletes from other sports.

Finally, new studies are suggested that aim to understand the athlete's adaptation to the new club, but using other resources to obtain information, such as the athlete's follow-up over time, collecting information with others who are involved with the adaptation of the athlete, for both Volleyball and other sports. Also, it is expected that further studies will be 
conducted evaluating the effectiveness of the programs of preparation of athletes for the expatriation.

\section{AUTHORS' CONTRIBUTION}

IWT and AAM: study design; JMM and DB: data analysis; VO and IWT: data collection; IWT, AAM, JMM and SD: critical revision of the manuscript and discussion. All authors read and approved the final manuscript.

\section{CONFLICT OF INTERESTS}

The authors declare that there was no conflict of interests.

\section{AUTHORS DETAILS}

(2) Universidade Estadual Paulista (Unesp), Rio Claro (SP), Brasil.

(3) Centro Universitário FIEO (UNIFIEO), Osasco, Brasil.

(4) Centro Universitário Salesiano de São Paulo (UNISAL), Americana, Brasil.

\section{REFERENCES}

1. Andreff W. Why Tax International Athlete Migration? The 'Coubertobin' Tax in a Context of Financial Crisis. In: Maguire J, Falcous M, editors. Handbook on Sport and Migration: Borders, Boundaries and Crossings. Oxon: Routledge; 2010. p. 31-45.

2. Tertuliano IW. Processo de expatriação de voleibolistas: Concepções Bioecológicas. [Tese de doutorado]. Rio Claro (SP): Universidade Estadual Paulista; 2016.

3. Andreff W. Globalization of the sports economy. Riv di Dirit ed Econ dello Sport. 2008;4(3):13-32.

4. Bizzocchi CC. O Voleibol de Alto Nível: da iniciação à competição. Barueri: Manole; 2008. 328 p.

5. Pontes VS, Ribeiro CH V., Garcia RM, Pereira EGB. Migração no Voleibol brasileiro: a perspectiva de atletas e treinadores de alto rendimento. Movimento. 2018;24(1):187-98.

6. Brandão MRF, Magnani A, Tega E, Medina JP. Além da cultura nacional : o expatriado no futebol. Rev Bras Ciência e Mov. 2013;21(2):177-82.

7. Faggiani FT, Strey A, Fuginiti D, Lindern D, Aiquel PF, Sartori C. O Fenômeno do Expatriado no Contexto Esportivo. Psicol Ciência e Profissão. 2016;36(3):738-47.

8. Tiesler NC. Three types of transnational players: differing women's football mobility projects in core and developing countries. Rev Bras Ciências do Esporte. 2016;38(2):201-10.

9. Rigo LC, Silva D V., Rial CSM. Formação de jogadores em clubes de uma cidade do interior: circulação, escolarização e inserção no Futebol profissional. Movimento. 2018;24(1):263-74.

10. Tibbert SJ, Andersen MB, Morris T. What a difference a "Mentally Toughening" year makes: The acculturation of a rookie. Psychol Sport Exerc. 2015;17:68-78.

11. Agergaard S, Ryba T V. Migration and Career Transitions in Professional Sports: Transnational Athletic Careers in a Psychological and Sociological Perspective. Sociol Sport J. 2014;31(2):228-47.
12. Schinke RJ, McGannon KR, Battochio RC, Wells GD. Acculturation in elite sport: a thematic analysis of immigrant athletes and coaches. J Sports Sci. 2013;31(15):1676-86.

13. Agergaard S. Elite athletes as migrants in Danish women's handball. Int Rev Sociol Sport. 2008;43(1):5-19.

14. Tertuliano IW, Machado AA, Deustch S, Montiel JM, Bartholomeu D. Motivos e intenções para expatriação de voleibolistas. Rev Adm Contemp. 2018;22(4):531-51.

15. Machado FS. Gestão de pessoas interncional no contexto esportivo brasileiro: uma análise dos processos de expatriação e repatriação de jogadores em um clube de futebol gaúcho. [Dissertação de Mestrado]. Porto Alegre (RS): Universidade Federal do Rio Grande do Sul; 2013.

16. Machado AA. Voleibol se aprende na escola. Várzea Paulista: Editora Fontoura; 2014.

17. Fontes RCC, Brandão MRF. A resiliência no âmbito esportivo: Uma perspectiva bioecológica do desenvolvimento humano. Motriz. 2013;19(1):151-9.

18. Pisani MS. Migrações e deslocamentos de jogadoras de futebol: mercadoria que ninguém compra? Esporte e Soc. 2014;9(23):1-11.

19. Green SB, Salkind NJ, Akey TM. Using SPSS for windows: analyzing and understanding data. 2nd ed. New Jersey: Prentice Hall; 2000.

20. Vockell EL. Educational research. New York: Macmillan; 1983

21. Cardoso PMS, Ribeiro CHV. Football and Migration: The process for transfer of players brasileiros for other countries. Fiep Bull. 2008;78:50-3.

22. Freitas LPR, Costa Neto JR, Cardoso RM, Ferreira MPP. Estudo do fenômeno do regresso de ex-atletas sul-mineiros de futebol do exterior. Lect Educ Física y Deport. 2012;16(164):1-9.

23. Pons J, Viladrich C, Ramis Y, Polman R. The Mediating Role of Coping between Competitive Anxiety and Sport Commitment in Adolescent Athletes. Span J Psychol. 2018;21:E7.

24. Vallerand RJ, Deci EL, Ryan RM. Intrinsic motivation in sport. Exerc Sport Sci Rev. 1987;15(1):389-426.

25. Lazarus RS. Emotion and adaptation. New York: Oxford University Press; 1991.

26. Deci EL, Ryan RM. Intrinsic motivation and self-determination in human behavior. New York: Plenum press; 1985.

27. Martens R, Vealey RS, Burton D. Competitive anxiety in sport. Champaign: Human Kinetics; 1990.

28. Oliveira LP. Motivação, estratégias de coping e perfeccionismo em atletas profissionalizados e não profissionalizados de futebol de campo. [Dissertação de Mestrado]. Maringá (PR): Universidade Estadual de Maringá; 2009.

29. Lundqvist C, Kenttä G, Raglin JS. Directional anxiety responses in elite and sub-elite young athletes: intensity of anxiety symptoms matters. candinavian J Med Sci Sport. 2011;21(6):853-62.

30. Keegan RJ, Harwood CG, Spray CM, Lavallee DE. A qualitative investigation exploring the motivational climate in early career sports participants: Coach, parent and peer influences on sport motivation. Psychol Sport Exerc. 2009;10(3):361-72. 